\title{
TRPC1-mediated $\mathrm{Ca}^{2+}$ entry is essential for the regulation of hypoxia and nutrient depletion-dependent autophagy
}

\author{
P Sukumaran ${ }^{1}$, Y Sun ${ }^{1}$, M Vyas $^{1}$ and BB Singh ${ }^{* 1}$
}

Autophagy is a cellular catabolic process needed for the degradation and recycling of protein aggregates and damaged organelles. Although $\mathrm{Ca}^{2+}$ is suggested to have an important role in cell survival, the ion channel(s) involved in autophagy have not been identified. Here we demonstrate that increase in intracellular $\mathrm{Ca}^{2+}$ via transient receptor potential canonical channel-1 (TRPC1) regulates autophagy, thereby preventing cell death in two morphologically distinct cells lines. The addition of DMOG or DFO, a cell permeable hypoxia-mimetic agents, or serum starvation, induces autophagy in both epithelial and neuronal cells. The induction of autophagy increases $\mathrm{Ca}^{2+}$ entry via the TRPC1 channel, which was inhibited by the addition of 2APB and SKF96365. Importantly, TRPC1-mediated $\mathrm{Ca}^{2+}$ entry resulted in increased expression of autophagic markers that prevented cell death. Furthermore, hypoxia-mediated autophagy also increased TRPC1, but not STIM1 or Orai1, expression. Silencing of TRPC1 or inhibition of autophagy by 3-methyladenine, but not TRPC3, attenuated hypoxia-induced increase in intracellular $\mathrm{Ca}^{2+}$ influx, decreased autophagy, and increased cell death. Furthermore, the primary salivary gland cells isolated from mice exposed to hypoxic conditions also showed increased expression of TRPC1 as well as increase in $\mathrm{Ca}^{2+}$ entry along with increased expression of autophagic markers. Altogether, we provide evidence for the involvement of $\mathrm{Ca}^{2+}$ influx via TRPC1 in regulating autophagy to protect against cell death.

Cell Death and Disease (2015) 6, e1674; doi:10.1038/cddis.2015.7; published online 5 March 2015

Autophagy is a cellular process responsible for the delivery of proteins or organelles to lysosomes for its degradation. Autophagy participates not only in maintaining cellular homeostasis, but also promotes cell survival during cellular stress situations. ${ }^{1,2}$ The stress conditions including nutrient starvation, hypoxia conditions, invading microbes, and tumor formation, have been shown to induce autophagy that allows cell survival in these stressful or pathological situations. ${ }^{1}$ In addition, autophagy also recycles existing cytoplasmic components to generate the molecules that are required to sustain the most vital cellular functions. ${ }^{3}$ Till date, three forms of autophagy have been identified, which are designated as chaperone-mediated autophagy, microautophagy, and macroautophagy. ${ }^{4}$ Although the precise mechanism as to how autophagy is initiated is not well understood, many of the genes first identified in yeast that are involved in autophagy have orthologs in other eukaryotes including human homologs. ${ }^{5,6}$ The presence of similar genes in all organisms suggests that autophagy might be a phenomenon that is evolutionally conserved that is essential for cell survival. In addition, since autophagy delivers a fresh pool of amino acids and other essential molecules to the cell, initiation of autophagy is highly beneficial particularly during nutritional stress situations or tissue remodeling during development and embryogenesis. ${ }^{6}$ Consequently, impaired or altered autophagy is often implicated in several pathologies, like neurodegenerative disorders and cancer, ${ }^{7-9}$ which again highlight its importance.

$\mathrm{Ca}^{2+}$ has a vital role in the regulation of a large number of cellular processes such as cell proliferation, survival, migration, invasion, motility, and apoptosis. ${ }^{10,11}$ To perform functions on such a broad spectrum, the cells have evolved multiple mechanisms regulating cellular $\mathrm{Ca}^{2+}$ levels, mainly by regulating the function of various $\mathrm{Ca}^{2+}$ channels present in different locations. Mitochondrial, ER, lysosomal, and cytosolic $\mathrm{Ca}^{2+}$ levels are regulated by $\mathrm{Ca}^{2+}$ permeable ion channels localized either on the membranes of the intracellular organelles or on the plasma membrane. ${ }^{10}$ The $\mathrm{Ca}^{2+}$ permeable channels, including families of TRPCs, Orais, voltage-gated, two-pore, mitochondrial $\mathrm{Ca}^{2+}$ uniporter, $\mathrm{IP}_{3}$, and ryanodine receptors have all been identified to contribute towards changes in intracellular $\mathrm{Ca}^{2+}\left(\left[\mathrm{Ca}^{2+}\right]_{\mathrm{i}}\right) .{ }^{10,12-14}$ Channels of the TRPCs and Orai families have been related to several $\mathrm{Ca}^{2+}$-dependent physiological processes in various cell types, ranging from cell proliferation to contractility, to apoptosis under both physiological and pathological conditions. $^{12}$ Moreover, it has been suggested that intracellular $\mathrm{Ca}^{2+}$ is one of the key regulators of autophagy; ${ }^{15}$ however, the possible role of $\mathrm{Ca}^{2+}$ in autophagy is still inconclusive. Many reports also suggest that $\mathrm{Ca}^{2+}$ inhibits

\footnotetext{
${ }^{1}$ Department of Basic Sciences, School of Medicine and Health Sciences, University of North Dakota, Grand Forks, ND 58201, USA

${ }^{*}$ Corresponding author: BB Singh, Department of Basic Sciences, School of Medicine and Health Sciences, University of North Dakota, Grand Forks, ND 58201, USA. Tel: +701 777 0834; Fax: +701 777 2382; E-mail: brij.singh@med.und.edu

Abbreviations: TRPC, transient receptor potential canonical; STIM1, stromal interaction molecule-1; ER, endoplasmic reticulum; DMOG, dimethyloxalylglycine; DFO, desferrioxamine; 2APB, 2-aminoethoxydiphenyl borate; SOC, store-operated calcium entry; $I_{3} R$, inositol 1,4,5, triphosphate $\left(I_{3}\right)$ receptor; Tg, thapsigargin; HSG, human salivary gland; mTOR, mammalian target of rapamycin; 3-MA, 3-methyladenine

Received 16.9.14; revised 04.12.14; accepted 29.12.14; Edited by A Verkhratsky
} 
autophagy, ${ }^{16-18}$ whereas others have indicated a stimulatory role for $\mathrm{Ca}^{2+}$ towards autophagy. ${ }^{19-21}$ Furthermore, the identity of the major $\mathrm{Ca}^{2+}$ channel(s) involved in autophagy is not known. Members of the TRPC family have been suggested as mediators of $\mathrm{Ca}^{2+}$ entry into cells. Activation of the G-protein ( $G_{q / 11}-P L C$ pathway) leads to the generation of second messenger $I_{P_{3}}{ }^{10,22} I_{3}$ binds to the $I P_{3} R$, which initiates $\mathrm{Ca}^{2+}$ release from the ER stores, thereby facilitating stromal interacting molecule-1 (STIM1) to rearrange and activate $\mathrm{Ca}^{2+}$ entry via the store-operated channels. ${ }^{22}$ Two families of proteins (TRPCs and Orais) have been identified as potential candidates for SOC-mediated $\mathrm{Ca}^{2+}$ entry. ${ }^{12,22} \mathrm{How}-$ ever, their role in autophagy has not yet been determined. Thus, here we investigated the role of $\mathrm{Ca}^{2+}$ entry channels (TRPCs and Orais) in autophagy and show that both hypoxiamimetic and nutrient depression induces autophagy in two different cell lines. Furthermore, our data indicates that autophagy was dependent on TRPC1-mediated increase in intracellular $\mathrm{Ca}^{2+}$ levels, suggesting that TRPC1 has an important role in regulating autophagy and inhibiting cell death.

\section{Results}

Hypoxic conditions and serum depletion induces autophagy in both epithelial and neuronal cells. The human salivary gland (HSG) cells and neuroblastic SHSY-5Y cells were treated with $1 \mathrm{mM}$ DMOG or DFO or were subjected to serum-free media. After treatment, the cells were lysed and expressions of the autophagic marker proteins were analyzed using western blotting. Both autophagic markers Beclin-1 and LC3A were upregulated in both cells treated with DMOG or DFO or in serum-deprived conditions (Figure 1a, quantification provided in Figure 1b). Similarly, ATG5 levels were also increased under these three conditions in both HSG and SHSY-5Y cells (data not shown). Importantly, it has been previously reported that p62 expression is lost when cells undergo autophagy. ${ }^{23}$ Thus, we also evaluated the expression of p62, which was significantly decreased in DMOG, DFO, and serumdeprived conditions (Figures $1 \mathrm{a}$ and $\mathrm{b}$ ). To have further evidence, we also evaluated the localization of LC3A as it has been previously reported that LC3B forms a punctate pattern when cells induce autophagy. ${ }^{24}$ Importantly, the confocal images of cells transfected with fluorescent-tagged LC3B and treated with DMOG or DFO for $24 \mathrm{~h}$, confirm the result that DMOG and DFO treatment in both HSG and SHSY-5Y cells induces autophagy (Figures 1c and d). Although both DMOG and DFO could induce hypoxia, they do not truly represent hypoxic conditions. In addition, to study the physiological responses in animal models, mice were exposed to $10 \%$ oxygen for 3 days. Protein were isolated from salivary glands of normoxia- (control) and hypoxiainduced mice, as mentioned previously. ${ }^{25}$ Similar to our cell culture results, LC3A expression was increased in mice exhibiting hypoxia conditions (Figure 1e, quantification provided as bar graph) suggesting that hypoxia induces autophagy in mouse models. a

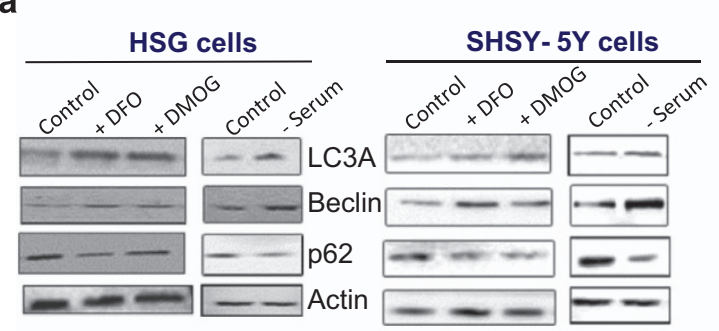

C

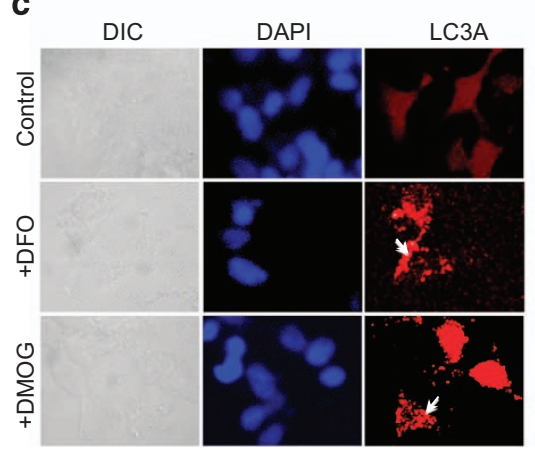

b

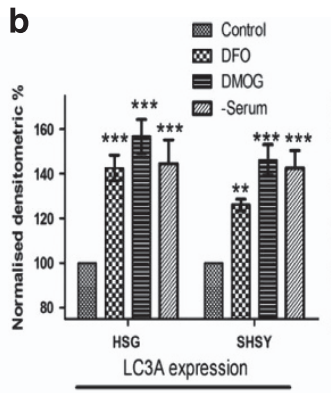

d

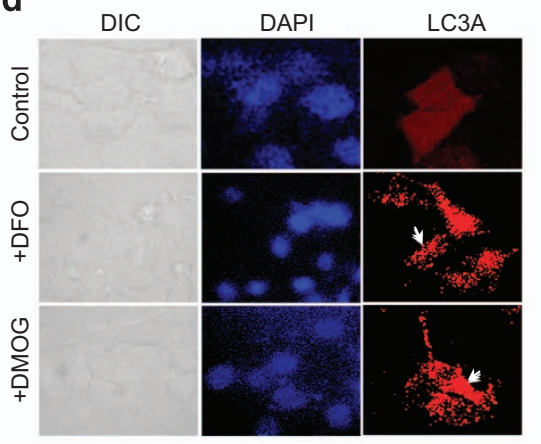

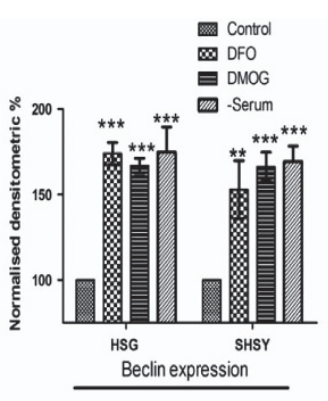

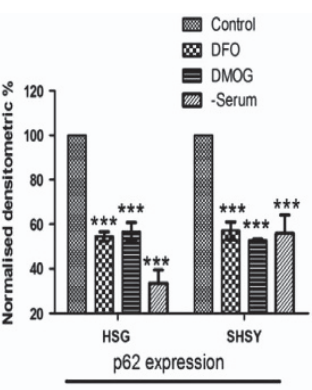

e

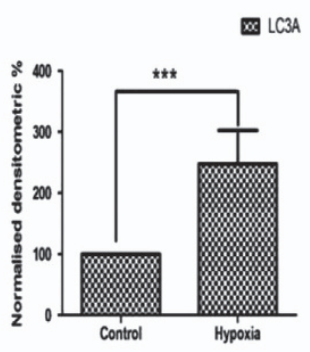

Figure 1 Induced Autophagy in SH-SY5Y and HSG cells. (a) HSG and SHSY-5Y cells were treated for $24 \mathrm{~h}$ with $1 \mathrm{mM} \mathrm{DFO}, 1 \mathrm{mM}$ DMOG, and in a serum-free media. Protein was isolated and western blots represent the protein expression of different autophagy marker beclin-1, LC3A, p62, and loading control actin. (b) Corresponding densitometric reading of the autophagy marker protein is shown as a bar diagram. Each bar gives the mean \pm S.E.M. of four separate experiments. ${ }^{*} P<0.05$, ${ }^{* \star} P<0.01$, and ${ }^{* * *} P<0.001$. Confocal image of HSG and SH-SY5Y cells, respectively, transfected with fluorescent-tagged LC3 and treated for $24 \mathrm{~h}$ with $200 \mu \mathrm{M} \mathrm{DFO}$ or $200 \mu \mathrm{M} \mathrm{DMOG}$. (c and d) Western blot images showing the expression of autophagy marker LC3A in primary salivary gland cells isolated from normoxia- and hypoxia-induced mice models. (e) Bar diagram representing the densitometric reading of the LC3A in the above-mentioned western blots. Each bar gives the mean \pm S.E.M. of four separate experiments 
To confirm that hypoxia-mimetic agents, DMOG and DFO, induce autophagy that inhibits apoptosis, cell viability assays were performed. Treatment with $1 \mathrm{mM}$ DMOG or $1 \mathrm{mM}$ DFO showed no significant decrease in cell viability in both SHSY-5Y and HSG cells (Figures $2 a$ and b). Moreover, the expression of caspase 3 , an apoptotic marker protein, was also not altered in cells treated with DMOG or DFO or serum starvation (Figures $2 \mathrm{c}$ and $\mathrm{d}$ ). Overall, these results suggest that DMOG, or DFO, or serum starvation induces autophagy in epithelial and neuronal cells that maintain cell viability perhaps by inhibiting apoptotic-mediated cell death.

Hypoxia and serum depletion induces increase in intracellular cytosolic $\mathrm{Ca}^{2+}$ levels. Agonist-stimulated $\mathrm{Ca}^{2+}$ entry has been suggested to have an essential role in regulating cell survival. ${ }^{26}$ Furthermore, alterations in intracellular $\mathrm{Ca}^{2+}$ levels has been shown to regulate autophagy. ${ }^{15}$ Thus, we next evaluated $\mathrm{Ca}^{2+}$ levels in both epithelial and neuronal cells. Cells were pretreated with $1 \mathrm{mM}$ DMOG or $1 \mathrm{mM}$ DFO or in serum-free media for $6 \mathrm{~h}$ and were then incubated with Fura-2 to measure intracellular $\mathrm{Ca}^{2+}$ levels in both SHSY-5Y and HSG cells. To evaluate $\mathrm{Ca}^{2+}$ entry, ER $\mathrm{Ca}^{2+}$ stores were depleted by the addition of thapsigargin (Tg, $2 \mu \mathrm{M})$. Importantly, in the absence of extracellular $\mathrm{Ca}^{2+}$, the increase in $\left[\mathrm{Ca}^{2+}\right]_{i}$ evoked by $\mathrm{Tg}$ (first peak) was not significantly different in DMOG-treated cells, when compared with untreated HSG cells (Figure $3 a$ ). In contrast, addition of external $\mathrm{Ca}^{2+}(1 \mathrm{mM})$, which initiates store-mediated $\mathrm{Ca}^{2+}$ entry, was significantly increased in DMOG-treated HSG cells (Figure 3a). Similar results were also obtained with serum starvation where a significant increase in $\mathrm{Ca}^{2+}$ entry was
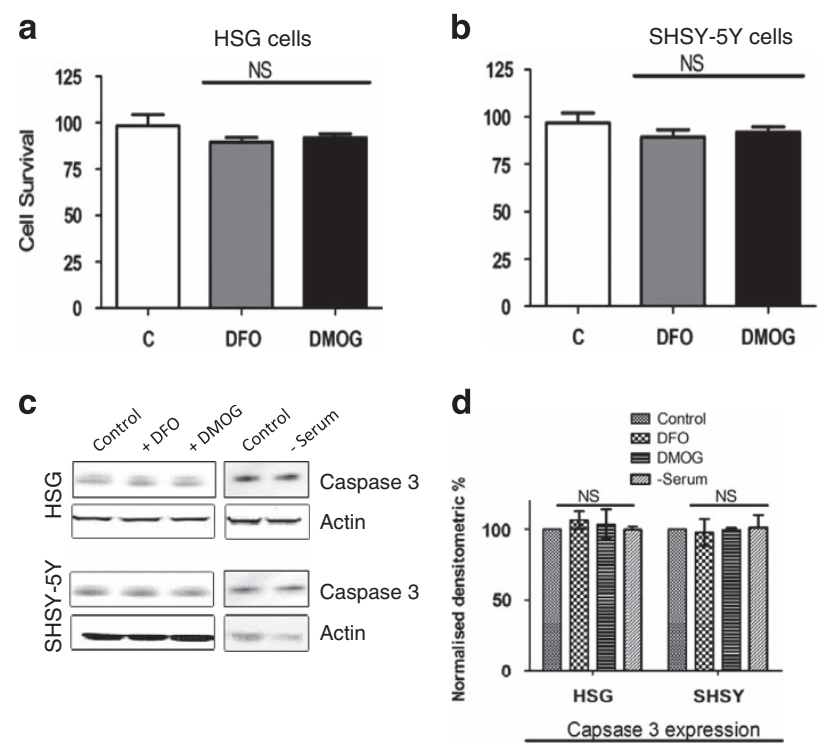

Figure 2 DMOG and DFO treatment effects on the cell viability or apoptosis in the cells. (a) Bar diagram showing the cell viability assay (MTT assay) in the HSG cells and (b) SHSY-5Y cells pretreated with $1 \mathrm{mM}$ of both DFO and DMOG. Each bar gives the mean \pm S.E.M. of four separate experiments. NS indicates no significance. (c) Western blot images showing the expression of caspase 3 in SHSY-5Y and HSG cells pretreated with $1 \mathrm{mM} \mathrm{DMOG}$ and $1 \mathrm{mM} \mathrm{DFO}$ or in serum-free media for $24 \mathrm{~h}$. (d) Bar diagram representing the densitometric reading of the caspase 3 expression in the above-mentioned western blots. Each bar gives the mean \pm S.E.M. of four separate experiments. NS indicates no significance observed in HSG cells that were serum starved (Figure 3b). Consistent with these results, DFO also showed a significant increase in $\mathrm{Ca}^{2+}$ entry (data not shown). We next compared if these effects are same in SHSY-5Y cells, and all hypoxicinducing treatments again resulted in an increase in $\left[\mathrm{Ca}^{2+}\right]_{i}$ activated by store depletion in SHSY-5Y (Figures 3c and d) cells. Primary salivary gland cells were isolated from control and hypoxia-treated mice, as mentioned previously ${ }^{27}$ and $\left[\mathrm{Ca}^{2+}\right]_{\mathrm{i}}$ levels were evaluated. Consistent with cell culture results, an increase in $\left[\mathrm{Ca}^{2+}\right]_{i}$ was again observed in cells isolated from salivary glands of hypoxia-induced mice (Figure $3 e$ ), when compared with cells from control mice. Altogether, these results suggest that conditions that induce autophagy increase $\left[\mathrm{Ca}^{2+}\right]_{\mathrm{i}}$ levels that might be essential for cell survival and in the induction of autophagy.

Inhibition of TRPC channel attenuated DMOG-induced increase in intracellular $\mathrm{Ca}^{2+}$ levels and decreased cell viability by inducing apoptosis. 2-Aminoethoxydiphenyl borate (2APB) and SKF96365 hydrochloride (SKF) are potent TRPC channel inhibitors; ${ }^{12}$ we thus investigated their role in autophagy. Importantly, in both SHSY-5Y and HSG cells, the increase in $\left[\mathrm{Ca}^{2+}\right]_{i}$ observed with DMOG treatment was attenuated in the presence of 2APB (Figure 4a) and SKF (Figure $4 \mathrm{~b}$ ). Similar results were also obtained with DFO or serum starvation where hypoxic-mediated increase in $\mathrm{Ca}^{2+}$ entry was decreased in cells treated with 2APB or SKF (data not shown). The cell viability was also affected when cells were pretreated with DMOG or DFO in the presence of TRPC channel inhibitor SKF, where a significant decrease in cell survival was observed (Figure 4c). Pretreatment of HSG cells with $1 \mathrm{mM}$ DMOG in the presence of SKF, also resulted in a loss of autophagy, where no increase in LC3A expression was observed (Figure 4d). Moreover, an increase in apoptosis marker caspase 3 was observed in HSG cells pretreated with DMOG and TRPC channel blocker SKF (Figure 4d). Similar results were also obtained with DFO and in SHSY-5Y cells (data not shown). To further confirm this, LC3A punctate formation was evaluated in both HSG and SHSY-5Y cells. As shown in Figures $4 \mathrm{e}$ and $\mathrm{f}$, no puncta formation of LC3B was observed in cells treated with DMOG or DFO along with SKF96365, further indicating that calcium entry via TRPC channels is essential for the induction of autophagy and inhibition of apoptosis.

Hypoxia and serum depletion increases TRPC1 expression and $\mathrm{Ca}^{2+}$ entry. To establish the identity of the $\mathrm{Ca}^{2+}$ entry channel, electrophysiological recordings were performed in hypoxia conditions. The addition of $\mathrm{Tg}$ caused the appearance of an inward current, which reversed between 0 and $-5 \mathrm{mV}$ in SHSY-5Y cells (Figures $5 a-d$ ) and in HSG cells (results not shown). Perfusion with Na-based DVF solution facilitated the current, which indicated the current is nonselective (Figure 5e). The channel properties were similar to those previously observed with TRPC1 channels, ${ }^{28}$ which was induced by store deletion (baseline currents without $\mathrm{Tg}$ are shown in $I-V$ curves), reversal potential around $0 \mathrm{mV}$, slightly inward rectifying and nonselective, suggesting that TRPC1 could contribute to the endogenous $\mathrm{Ca}^{2+}$ entry channel in these cells. Importantly, DMOG and DFO 
a
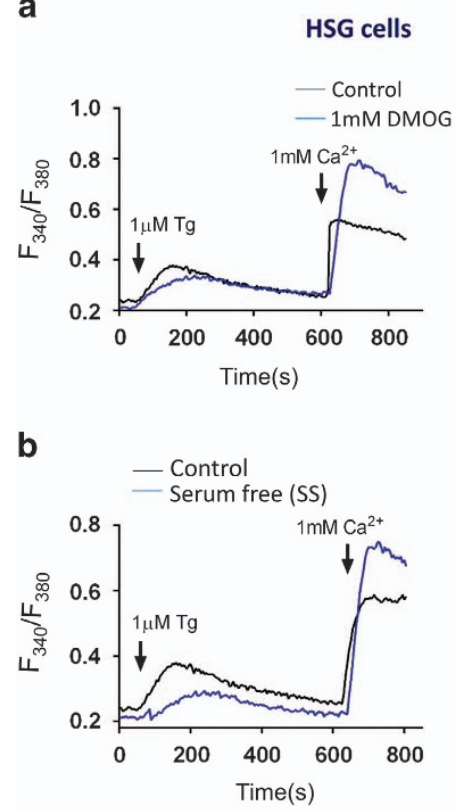
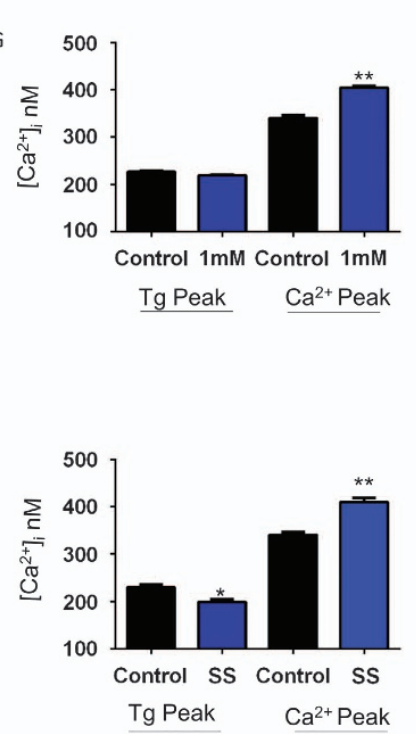

C

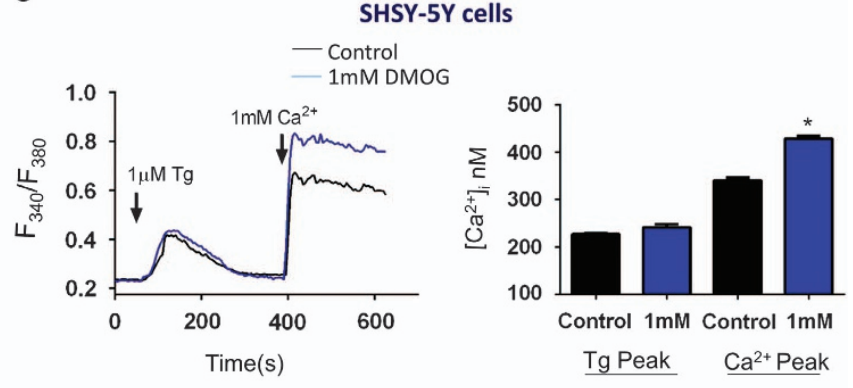

e

d

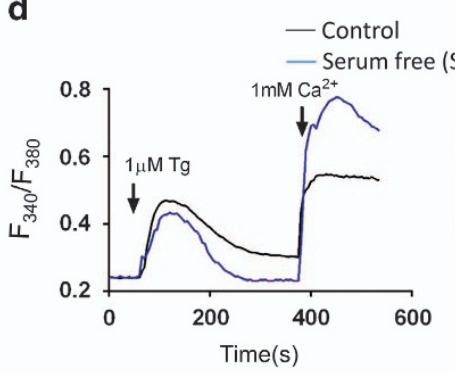

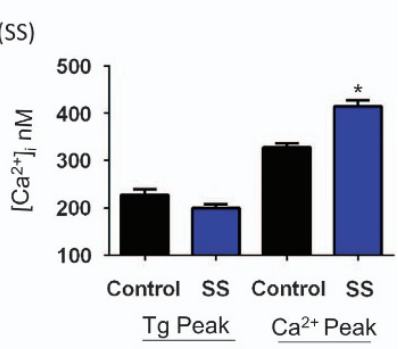
Mice primary salivary gland cells
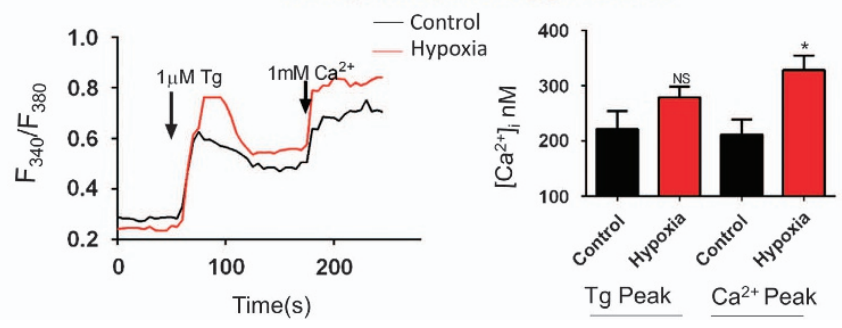

Figure 3 Increase intracellular calcium in autophagy induces cells. Representative traces showing the transient increase in $\left[\mathrm{Ca}^{2+}\right]_{i}$ after addition of $1 \mathrm{mM}$ calcium to $\mathrm{HSG}$ cells (a) and in SHSY-5Y cells (b) pretreated with $1 \mathrm{mM} \mathrm{DMOG}$. Bar diagram shows the $\left[\mathrm{Ca}^{2+}\right]_{\mathrm{i}}$ in $\mathrm{nM}$ concentration of the above-mentioned experiment. Each bar gives the mean \pm S.E.M. of 50 separate experiments. ${ }^{*} P<0.05$ and ${ }^{* *} P<0.01$. Representative traces showing the transient increase in $\left[\mathrm{Ca}^{2+}\right]_{\mathrm{i}}$ after the addition of $1 \mathrm{mM}$ calcium to HSG cells (c) and in SHSY-5Y cells (d) pretreated with serum-free media. Bar diagram shows the $\left[\mathrm{Ca}^{2+}\right]_{\mathrm{i}}$ in $\mathrm{nM}$ concentration of the above-mentioned experiment. Each bar gives the mean \pm S.E.M. of 45 separate experiments. ${ }^{*} P<0.05$ and ${ }^{* *} P<0.01$. (e) Representative traces showing the transient increase in $\left[\mathrm{Ca}^{2+}\right]_{\text {i }}$ after addition of $1 \mathrm{mM}$ calcium in primary salivary gland cells isolated from the hypoxia induce mice model when compared to the control (normoxia) samples. Bar diagram shows the $\left[\mathrm{Ca}^{2+}\right]_{\mathrm{i}}$ in nM concentration of the above-mentioned experiment. Each bar gives the mean \pm S.E.M. of 20 separate cells. ${ }^{*} P<0.05$

treatment significantly facilitated TRPC1-mediated $\mathrm{Ca}^{2+}$ currents without altering the current-voltage $(I-V)$ relationship (Figure 5a-d). Moreover, electrophysiological recordings using dispersed salivary gland cells also showed an inward nonselective current upon addition of $\mathrm{Tg}$, which are consistent with previous results. ${ }^{27,29}$ The properties of the current are similar to TRPC1 current and more importantly, hypoxiatreated cells significantly facilitated the Tg-mediated $\mathrm{I}_{\mathrm{soc}^{-}}$ currents (Figures $5 f$ and $g$ ). To further identify the cellular component of $\mathrm{Ca}^{2+}$ entry channel(s) involved in this process, cell lysates were obtained under these conditions and were used to evaluate the expression of various proteins involved in $\mathrm{Ca}^{2+}$ entry. Importantly, cells pretreated with $1 \mathrm{mM} \mathrm{DMOG}$, or $1 \mathrm{mM}$ DFO, or in serum-free media showed a significant increase in TRPC1 levels (Figure 5h). In contrast, no significant change in either STIM1 or Orai1 expression levels were observed in hypoxia or serum-depletion conditions in both SHSY-5Y and HSG cells (Figures $5 \mathrm{~h}$ and i). TRPC1 expression was also increased in hypoxia-induced mice models (Figure 5j). To further establish as to how hypoxia- increased calcium entry surface expression of TRPC1 was observed in SHSY-5Y cells, cells were pretreated with $1 \mathrm{mM}$ DMOG or $1 \mathrm{mM}$ DFO. As indicated in Figure $5 \mathrm{k}$, cells treated with DFO or DMOG showed increase in surface expression of TRPC1, but not transferrin receptor (as internal control), which could account for the increase in hypoxia-mediated $\mathrm{Ca}^{2+}$ currents observed above. Consistent with previous reports, ${ }^{30}$ addition of thapsigargin also induced surface expression of TRPC1 (as positive control). Hereby, our data indicate that autophagy was dependent on TRPC1, suggesting that TRPC1 has an important role in regulating hypoxia inducing autophagy and inhibiting cell death.

Knockdown of TRPC1, but not TRPC3, or inhibition of autophagy attenuated DMOG and serum depletion induced increase in intracellular $\mathrm{Ca}^{2+}$ and affects cell viability. Data presented thus far indicate that TRPC1 could be important for hypoxia- and serum starvation induced increase in $\mathrm{Ca}^{2+}$ entry and could modulate autophagy. Thus, to study the importance of TRPC1 channels in hypoxia and 


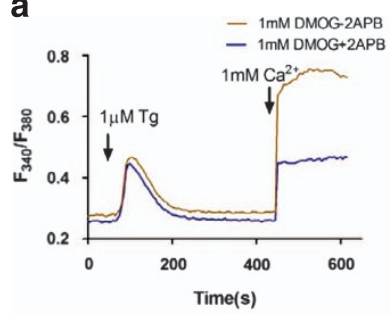

b

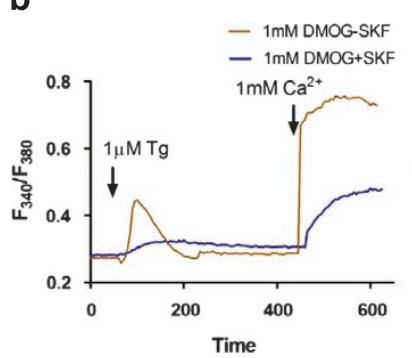

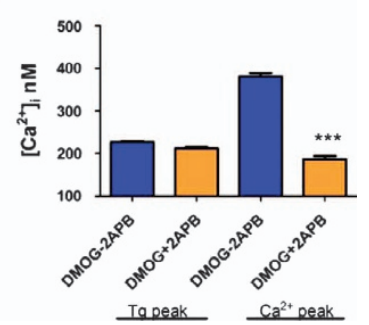

c

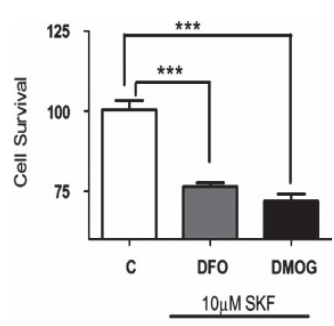

d

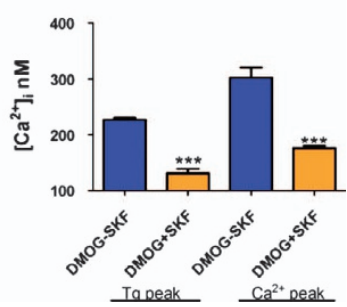

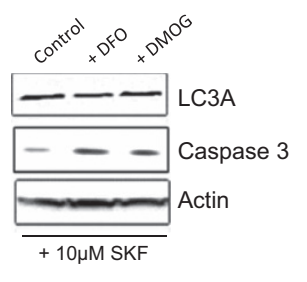

e
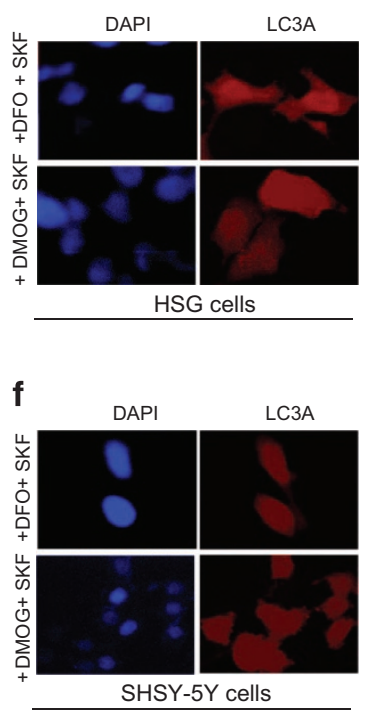

Figure 4 TRPC channel inhibitors attenuate the increase intracellular calcium in autophagy induces cells. (a) Representative traces showing the transient increase in $\left[\mathrm{Ca}^{2+}\right]_{\mathrm{i}}$ after the addition of $1 \mathrm{mM}$ calcium in the presence of $50 \mu \mathrm{M} 2 \mathrm{APB}$ to SHSY-5Y cells pretreated with $1 \mathrm{mM} \mathrm{DMOG}$. Bar diagram shows the [Ca $\left.{ }^{2+}\right]_{\mathrm{i}}$ in $\mathrm{nM}$ concentration of the abovementioned experiment. Each bar gives the mean \pm S.E.M. of 50 separate experiments. $e^{* \star} P<0.01$ and ${ }^{* \star *} P<0.001$. (b) Representative traces showing the transient increase in $\left[\mathrm{Ca}^{2+}\right]_{\mathrm{i}}$ after the addition of $1 \mathrm{mM}$ calcium in the presence of $10 \mu \mathrm{M} \mathrm{SKF}$ to SHSY-5Y cells pretreated with $1 \mathrm{mM} \mathrm{DMOG}$. Bar diagram shows the [Ca $\left.{ }^{2+}\right]_{\mathrm{i}}$ in $\mathrm{nM}$ concentration of the above-mentioned experiment. Each bar gives the mean \pm S.E.M. of 50 separate experiments. ${ }^{* *} P<0.01$ and ${ }^{* * *} P<0.001$. (c) Bar diagram showing the cell viability assay (MTT assay) in the SHSY-5Y cells, pretreated with $1 \mathrm{mM} \mathrm{DMOG}$ in the presence of $10 \mu \mathrm{M}$ SKF. Each bar gives the mean \pm S.E.M. of four separate experiments. ${ }^{\star *} P<0.01$ and ${ }^{* * *} P<0.001$. (d) Western blot images showing the expression of LC3A, caspase 3 in SHSY-5Y cells pretreated with $1 \mathrm{mM} \mathrm{DMOG}$ and $10 \mu \mathrm{M}$ SKF. Confocal image of HSG (e) and SH-SY5Y (f) cells transfected with GFP-LC3 and treated with $200 \mu \mathrm{M}$ DFO or $200 \mu \mathrm{M}$ DMOG and $10 \mu \mathrm{M}$ SKF

serum depletion-induced autophagy, we knocked down TRPC1 in both SHSY-5Y and HSG cells using siRNA $(70 \%$ knockdown Figures $6 \mathrm{a}$ and $\mathrm{c}$ shown as insets). Importantly, the DMOG- and serum depletion-induced increase in $\mathrm{Ca}^{2+}$ entry was attenuated in TRPC1 knockdown cells in both SHSY-5Y and HSG cells (Figures 6a-d). Moreover, pretreatment of DMOG, or DFO or serum-free media in TRPC1 knockdown cells also showed an increase in apoptosis (Figure 6e) and autophagy was inhibited as observed by beclin-1 levels (Figure 6f). To further position TRPC1 as the main calcium channel responsible for the currents induced by hypoxia, we knocked down TRPC3 in these cells. We first investigated the TRPC3 channel activity, which was induced by the application of OAG and addition of OAG induced an inward current, which was abolished by the expression of siTRPC3 (Figure 6g). More importantly, siTRPC3 has no significant effect on hypoxia- (1 mM DFO treatment) induced increase in Tg-induced currents (Figure 6h) and LC3A expression (Figure 6i). Collectively, these results suggest that hypoxia and serum starvation-mediated increase in $\mathrm{Ca}^{2+}$ entry is at least in part mediated via the TRPC1 channel, which could lead to the activation of autophagy that together would inhibit cell death in SHSY-5Y and HSG cells.

To further understand the link between $\mathrm{Ca}^{2+}$ entry via the TRPC1 channel and autophagy, 3-methyladenine (3-MA) a known autophagy inhibitor, ${ }^{4}$ was used. The cells were pretreated with $1 \mathrm{mM} 3-\mathrm{MA}$, along with DMOG, or DFO, or serum-free media and protein expression of STIM1, Orai1, TRPC1, and autophagy markers were analyzed. Importantly, cells treated with 3-MA showed no increase in DMOG or serum-deprived increase in TRPC1 expression (Figure 7a). Furthermore, no increase in beclin-1 an autophagic marker was observed in cells pretreated with 3-MA along with DMOGor serum-deprived conditions (Figure 7a). Pretreatment with 3-MA also attenuated the increase in $\mathrm{Ca}^{2+}$ entry that was induced by DMOG and serum starvation in both SHSY-5Y (Figures $7 b$ and $c$ ) and HSG cells (result not shown). Consistent with these results, pretreatment with 3-MA also attenuated cell viability (Figure $7 d$ ) and serum starvation induced increase in Tg-induced $\mathrm{Ca}^{2+}$ currents (Figures 7e and f). Altogether, these data suggest that $\mathrm{Ca}^{2+}$ entry via the TRPC1 channel is essential for autophagy that leads to the inhibition of cell death and loss of TRPC1 function or autophagy could lead to decrease in cell survival.

\section{Discussion}

When cells encounter stressful situations, like nutrient depletion or hypoxia they either try to survive under these conditions by coping with the stress, or can activate a programmed cell death mechanism such as apoptosis. ${ }^{2}$ One of the most beneficial processes during stress adaptation is the stimulation of autophagy, a lysosomal delivery pathway. ${ }^{6}$ Autophagy is also a major pathway needed for the clearance of pathogens in immunity and helps in maintaining cellular homeostasis. ${ }^{15}$ In 1993, Gordon et al. ${ }^{31}$ first reported on $\mathrm{Ca}^{2+}$-dependent regulation of autophagy and suggested a complex role for $\mathrm{Ca}^{2+}$, as both chelation of either intra- and extracellular $\mathrm{Ca}^{2+}$ as well as elevating cytosolic $\left[\mathrm{Ca}^{2+}\right]_{i}$ levels suppressed autophagy. This dichotomy could be due to the amount of 


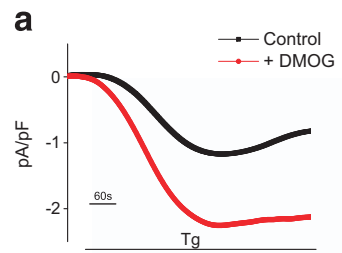

b

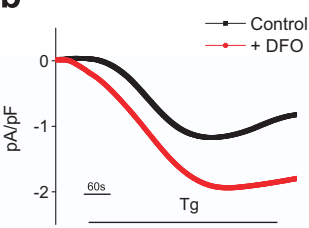

c

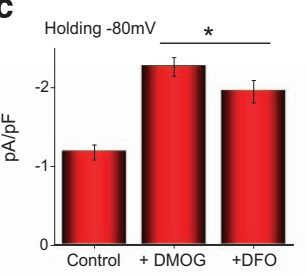

d

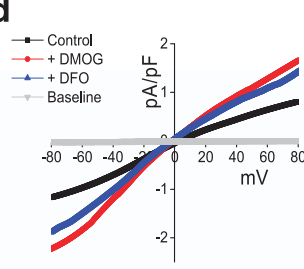

e

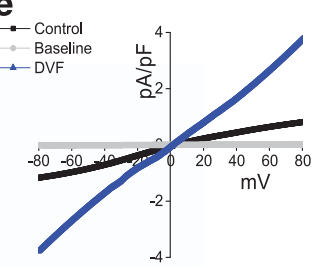

f

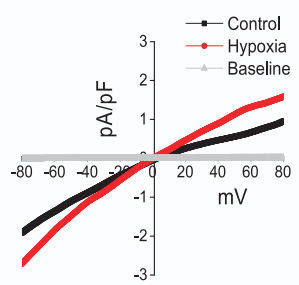

i

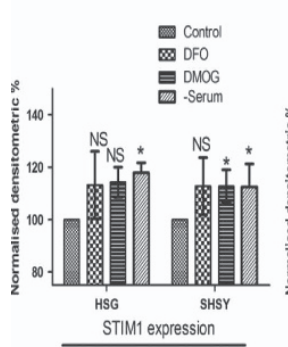

g

h
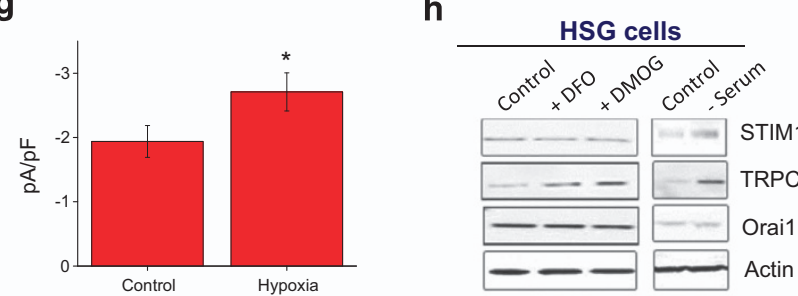

j

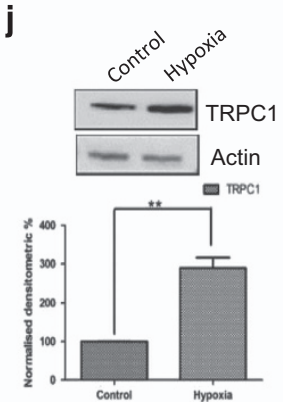

SHSY-5Y cells

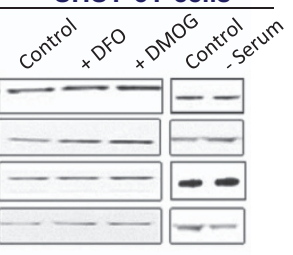

k

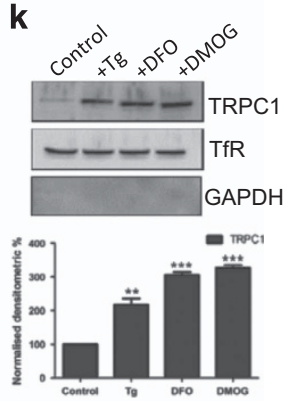

Figure 5 Increases in TRPC1 expression and currents in autophagy-induced HSG and SHSY-5Y cells. (a and $\mathbf{b})$ Application of $1 \mu \mathrm{M}$ Tg in bath solution induced inward currents at $-80 \mathrm{mV}$ in control, $1 \mathrm{mM}$ DMOG-, and $1 \mathrm{mM}$ DFO-treated cells. (c and d) Respectively $1-V$ curves under these conditions are shown in c and quantitation (8-10 recordings) of current intensity at $-80 \mathrm{mV}$ is shown in $\mathbf{d},{ }^{*} P=<0.05$. (e) $l-V$ curves of currents induced by the application of $1 \mu \mathrm{M} \mathrm{Tg}$ in standard external Ringer's solution and Na-based DVF external solutions. (f) Bath application of $1 \mu \mathrm{M}$ Tg in bath solution induced in salivary gland cells and relative $1-V$ curves. (g) Average (8-10 recordings) current intensity at $-80 \mathrm{mV}$ under these conditions is shown, ${ }^{*} P=<0.05$. (h) Represents western blot images showing the expression of SOCE components, STIM1, Orai1, and TRPC1 in HSG and SHSY-5Y cells pretreated with $1 \mathrm{mM} \mathrm{DMOG}$ and $1 \mathrm{mM} \mathrm{DFO}$ for $24 \mathrm{~h}$. Corresponding densitometric reading of the protein is shown as a bar diagram (i). Each bar gives the mean \pm S.E.M. of four separate experiments. ${ }^{*} P<0.05,{ }^{* \star} P<0.01$, and ${ }^{* \star *} P<0.001$. (j) Western blot images showing the expression of TRPC1 in primary salivary gland cells isolated from control and hypoxia-induced mice models. Bar diagram representing the densitometric reading of the TRPC1 in the above-mentioned western blots. Each bar gives the mean \pm S.E.M. of four separate experiments. (k) Western blot images showing the relative surface expression of TRPC1 obtained from cell surface biotinylation. Bar diagram shows the normalized expression of TRPC1 to the expression of cell surface transferrin receptor (TfR) protein. Each bar gives the mean \pm S.E.M. of three separate experiments

increase in $\mathrm{Ca}^{2+}$ as well as the source of $\mathrm{Ca}^{2+}$ entry. Our data suggest that a slight increase in $\mathrm{Ca}^{2+}$ entry was actually protective under these stressful conditions. Importantly, $\mathrm{Ca}^{2+}$ has also been shown to promote cell proliferation as well as induce apoptosis, ${ }^{32-34}$ suggesting that $\mathrm{Ca}^{2+}$ entry through different channels might dictate the fate of the cell differently. Consistent with this notion, treatments with AMPA or $\mathrm{KCl}$ have shown to increase $\left[\mathrm{Ca}^{2+}\right]_{i}$ without causing toxicity, ${ }^{35,36}$ whereas equally high $\mathrm{Ca}^{2+}$ loads were shown to be toxic when $\mathrm{Ca}^{2+}$ enters via the NMDA channels. ${ }^{37}$ Furthermore, in some cells, decreasing $\left[\mathrm{Ca}^{2+}\right]_{i}$ could be toxic, whereas in others, modest increase in $\left[\mathrm{Ca}^{2+}\right]_{i}$ can be protective, indicating a 'set-point' mechanism for the effect of $\left[\mathrm{Ca}^{2+}\right]_{i}$ in various cells. ${ }^{12,26,38,39}$

The notion that $\mathrm{Ca}^{2+}$ is important for cell survival is not new, but only recently has this topic regained interest. However, the published results are again conflicting with regard to the role of intracellular $\mathrm{Ca}^{2+}$ in autophagy. Many reports suggest that $\mathrm{Ca}^{2+}$ and $\mathrm{Ca}^{2+}$-handling proteins inhibit autophagy, ${ }^{16-18}$ whereas other reports indicate a stimulatory role for $\mathrm{Ca}^{2+}$ toward autophagy. ${ }^{19-21}$ Our data support the idea that $\mathrm{Ca}^{2+}$ entry via
TRPC1 is essential for the induction of autophagy. $\mathrm{Ca}^{2+}$ mediated inhibition of autophagy has been mostly focused on inositol 1,4,5, triphosphate $\left(\mathrm{IP}_{3}\right)$ receptor $\left(\mathrm{IP}_{3} \mathrm{R}\right){ }^{15,16}$ In Huntington's disease cell model, lithium ions have been shown to stimulate autophagy in a novel mTOR-independent manner. ${ }^{40}$ Lithium acted through inhibition of the inositol monophosphatases, thereby reducing the $\mathrm{IP}_{3}$ levels, which reduced the stimulatory effect of lithium on autophagy. This is consistent with the $\mathrm{IP}_{3} \mathrm{R}$ triple knockout chicken DT40 cells, which showed higher autophagy levels than their wild-type counterparts, verifying the $I_{3} R$-mediated inhibition of autophagy. ${ }^{18}$ Autophagy has also been shown to be initiated by chemical inhibition of $\mathrm{IP}_{3} \mathrm{Rs}$ or suppressing its expression thereby suppressing the $\mathrm{Ca}^{2+}$ signaling ${ }^{41}$ This is consistent with our data as loss of $I P_{3} R$ will have a decrease in TRPC1mediated $\mathrm{Ca}^{2+}$ entry. Although we have not fully identified the mechanism as to how TRPC1 regulates autophagy, it has been shown that $\mathrm{IP}_{3} \mathrm{Rs}$ facilitate the formation of antiautophagic Bcl-2-Beclin-1 complex thereby decreasing the amount of free Beclin-1 available to induce autophagy. We suggest that perhaps similar mechanism might be present 
a

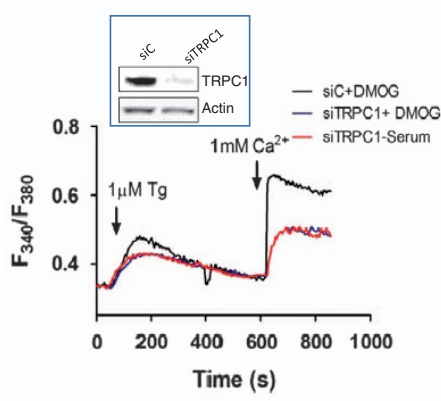

b

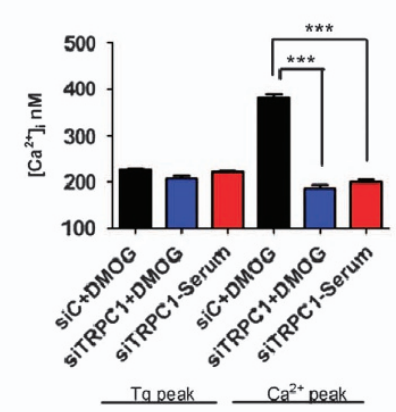

C

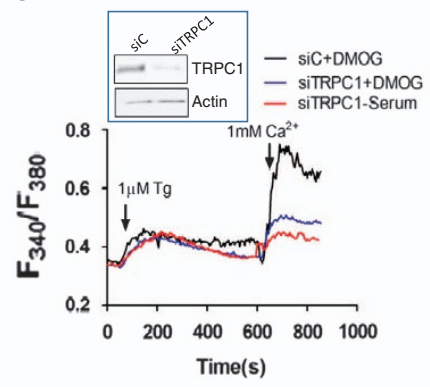

d

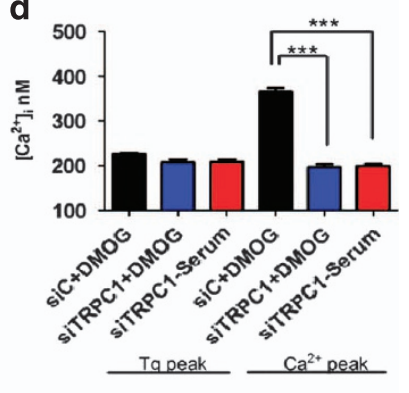

e

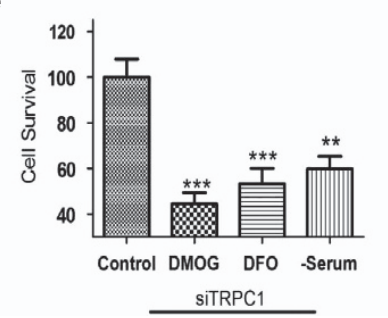

f

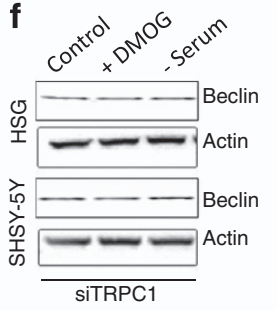

g

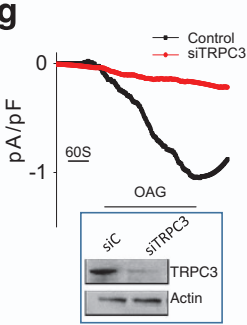

h

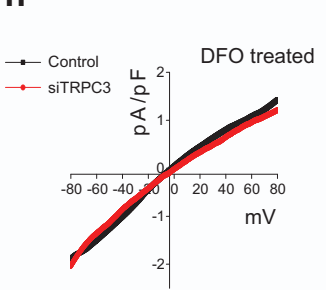

i

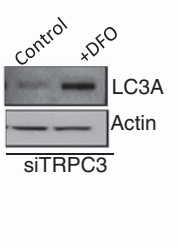

Figure 6 Knockdown of TRPC1 attenuated the autophagy-induced intracellular calcium increase and also affects the cell viability. Western blot images showing the knockdown of TRPC1 using siRNA, HSG cells (a) (70\% knockdown, $n=3, P<0.01$ ), and SHSY-5Y cells (b) ( $72 \%$ knockdown, $n=3, p<0.001)$. Representative traces showing the transient increase in $\left[\mathrm{Ca}^{2+}\right]_{\text {i }}$ after the addition of $1 \mathrm{mM}$ calcium to siRNATRPC 1 knockdown HSG cells (a) and in SHSY-5Y cells (b) pretreated with $1 \mathrm{mM}$ DMOG or in serumfree media. Bar diagram ( $\mathbf{c}$ and $\mathbf{d})$ shows the $\left[\mathrm{Ca}^{2+}\right]$ in $\mathrm{nM}$ concentration of the above-mentioned experiment. Each bar gives the mean $\pm \mathrm{S}$.E.M. of 40 separate cells. ${ }^{*} P<0.05$ and ${ }^{\star \star *} P<0.001$. (e) Bar diagram showing the cell viability assay (MTT assay) in the TRPC1 knockdown SHSY-5Y cells, pretreated with $1 \mathrm{mM}$ DMOG or $1 \mathrm{mM}$ DFO or in serumfree media. Each bar gives the mean \pm S.E.M. of four separate experiments. ${ }^{* *} P<0.01$. (f) Western blot images showing the expression of autophagy marker beclin-1 in HSG and SHSY-5Y cells pretreated with $1 \mathrm{mM} \mathrm{DMOG}$ or in serum-free media for $24 \mathrm{~h}$. $(\mathrm{g})$ Western blot image showing the TRPC3 knockdown using siRNA in SHSY-5Y cells $(60 \%$ knockdown, $n=3, P<0.01$ ). Application of $50 \mu \mathrm{M}$ OAG in bath solution induced inward currents at $-80 \mathrm{mV}$ in control and TRPC3 knockout cells. (h) Under DFO treatment, respectively $I-V$ curves of currents induced by the application of $1 \mu \mathrm{M} \mathrm{Tg}$ in control and TRPC3 knockout cells treated with $1 \mathrm{mM}$ DFO. The traces are representative of average (8-10 recordings) of current intensity at $-80 \mathrm{mV}$. (i) Western blot images showing the expression of LC3A in siTRPC3 SHSY-5Y cells with and without $24 \mathrm{~h}$ pretreatment with $1 \mathrm{mM} \mathrm{DFO}(n=3, P<0.05)$

where binding of $I P_{3} R$ with TRPC1 will inhibit the formation of anti-autophagic complex and more research is needed to understand the mechanism via which TRPC1 regulates autophagy. Binding of xestospongin-B to the $I P_{3} R$ also induced the dissociation of the complex, which was prevented by $\mathrm{Bcl}-2$ overexpression, whereas siRNA against $\mathrm{Bcl}-2$ abolished the $\mathrm{IP}_{3} \mathrm{R}$-Beclin-1 interaction. ${ }^{17}$

$\mathrm{Ca}^{2+}$ mobilizing agents, like ionomycin, ATP, vitamin D3, sarco/endoplasmic reticulum $\mathrm{Ca}^{2+}$ ATPase (SERCA) inhibitors thapsigargin and alisol have been reported to act as an activator of autophagy by elevating $\left[\mathrm{Ca}^{2+}\right]_{\mathrm{i} .}{ }^{7,19,39,42,43}$ Our data not only support these studies, but also identify that $\mathrm{Ca}^{2+}$ entry via TRPC1 is essential for autophagy. Of course, prolonged treatment with these agents will lead to $\mathrm{ER} \mathrm{Ca}^{2+}$ depletion and subsequent ER stress, which itself might also be a trigger for autophagy. The addition of BAPTA-AM, a fast and potent intracellular $\mathrm{Ca}^{2+}$ buffer, however, prevented the induction of autophagy, indicating the importance of cytosolic $\mathrm{Ca}^{2+} .44$ The thapsigargin-induced autophagy was still present in unfolded protein response (UPR)-deficient cells, suggesting again a direct involvement of $\mathrm{Ca}^{2+}$ in the induction of autophagy. ${ }^{45}$ The nutrient deprivation-induced autophagy was also inhibited by BAPTA-AM, ${ }^{46}$ suggesting that other autophagy inducers (like starvation, rapamycin, etc.) might also lead via enhanced $\mathrm{Ca}^{2+}$ signaling to autophagy induction, ${ }^{15}$ which is again consistent with the data presented here. Although our data suggest that TRPC1 was important for autophagy (as silencing of TRPC1, but not TRPC3, inhibited autophagy), we cannot completely rule out the possible role of other $\mathrm{Ca}^{2+}$ channels in this process. Gordon et al. ${ }^{31}$ already suggested the dependence of autophagy on intracellular stored $\mathrm{Ca}^{2+}$ and most $\mathrm{Ca}^{2+}$-mobilizing agents promote $\mathrm{Ca}^{2+}$ release from the $\mathrm{ER}^{15} \mathrm{Ca}^{2+}$-dependent autophagy is also enhanced by the pharmacological agent PK11195. ${ }^{47}$ Similarly, it has been shown that inhibition of plasma membrane $\mathrm{Ca}^{2+}$ channels prevented the autophagy induction caused by the increase of intra-axonal $\mathrm{Ca}^{2+}$ in the rat optic nerve after crush lesion; ${ }^{48}$ however, the source as well as the $\mathrm{Ca}^{2+}$ channels responsible for this has not been identified. These results along with the data presented here clearly show that the ER is probably the main, but not the only origin for $\mathrm{Ca}^{2+}$ during $\mathrm{Ca}^{2+}$-induced autophagy. Lowering of ER $\left[\mathrm{Ca}^{2+}\right]$ also prevents apoptosis driven by mitochondrial $\mathrm{Ca}^{2+}$ overload, underscoring that both autophagy and apoptosis are closely related. ${ }^{15}$ Our data also suggest that $\mathrm{Ca}^{2+}$ entry via the TRPC1 channel was initially protective. However, most of the compounds used for $\mathrm{Ca}^{2+}$-induced autophagy have also been shown to promote apoptosis. 3,7,15,19,39 Therefore, one might propose that autophagy is indirectly activated by $\mathrm{Ca}^{2+}$ that tries to counter apoptosis $^{20}$ to protect these cells and loss of these functions could perhaps lead to apoptosis. Here, thus we propose a model where increase in intracellular $\mathrm{Ca}^{2+}$ via TRPC1 channel promotes autophagy before the activation of apoptosis and increases cell survival. 
a

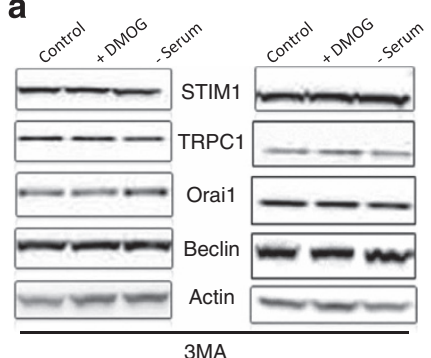

b

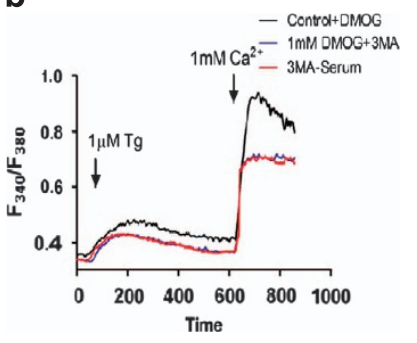

C

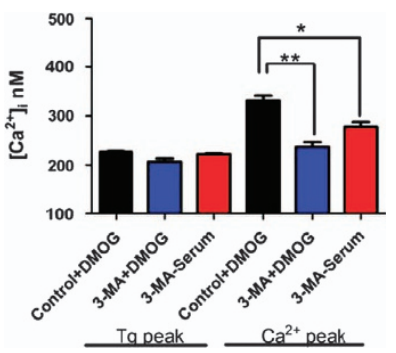

d

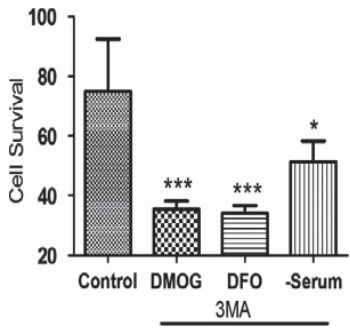

e

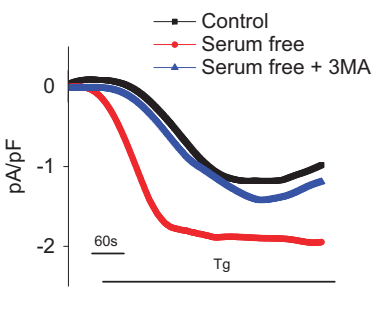

f

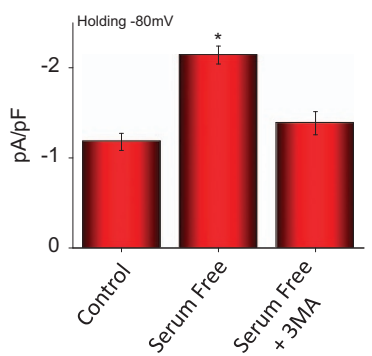

Figure 7 Pretreatment with autophagy inhibitor 3-methyladenine (3-MA) attenuated the intracellular calcium influx and induces apoptosis. (a) Western blot images showing the expression of SOCE components STIM1, TRPC1, and Orai1, autophagy marker beclin-1 and loading control actin in HSG and SHSY-5Y cells pretreated with 1 mM DMOG or in serum-free media in the presence of $1 \mathrm{mM}$ autophagy marker 3-MA for $24 \mathrm{~h}$. (b) Representative traces showing the transient increase in $\left[\mathrm{Ca}^{2+}\right]_{i}$ after the addition of $1 \mathrm{mM}$ calcium in the presence of $1 \mathrm{mM} 3-\mathrm{MA}$ to SHSY-5Y cells pretreated with $1 \mathrm{mM} \mathrm{DMOG}$ or in serum-free media. (c) Bar diagram shows the [C $\left.{ }^{2+}\right]_{\mathrm{i}}$ in nM concentration of the above-mentioned experiment. Each bar gives the mean \pm S.E.M. of 50 separate experiments. ${ }^{*} P<0.05,{ }^{* \star} P<0.01$. (d) Bar diagram showing the cell viability assay (MTT assay) in the SH-SY5Y cells, pretreated with $1 \mathrm{mM} \mathrm{DMOG}$ in the presence of $1 \mathrm{mM}$. Each bar gives the mean \pm S.E.M. of four separate experiments. ${ }^{* \star *} P<0.001$. (e) Application of $1 \mu \mathrm{M} \mathrm{Tg}$ in bath solution induced inward currents at $-80 \mathrm{mV}$ in control, cells treated in serum-free media and autophagy inhibitor 3-MA-treated cells. (f) Average (8-10) recordings current intensity at $-80 \mathrm{mV}$ are shown, ${ }^{*} P<0.05$

\begin{abstract}
Materials and Methods
Cell culture, animals, reagents, transfections, and RNAi. Human salivary gland (HSG) cells and SHSY-5Y neuroblastoma cells were cultured in their respective medium along with various supplements, as previously described. ${ }^{32,49,50}$ Cells were maintained at $37^{\circ} \mathrm{C}$ with $95 \%$ humidified air and $5 \% \mathrm{CO}_{2}$ and were passaged as needed. Culture medium was changed twice weekly and cells were maintained in complete media, until reaching $90 \%$ confluence. For RNAi experiments, siRNA that targets the coding sequence of human TRPC1 or TRPC3 were obtained from Ambion (Life Technology, Carlsbad, CA, USA) and a FITCconjugated non targeting siRNA was used as control. Cells were transfected with individual siRNA ( $50 \mathrm{nM}$ ) using Lipofectamine 2000 in Opti-MEM medium as per supplier's instructions (Invitrogen, Life Technology) and assayed after $48 \mathrm{~h}$. Antibodies that were used in this study are described in the figures. All other reagents used were of molecular biology grade obtained from Sigma (St. Louis, MO, USA) chemicals unless mentioned otherwise. To subject mice to chronic hypoxia, mice were placed in a plexiglass chamber maintained at $21 \%$ (normal) or $10 \% \mathrm{O}_{2}$ (hypoxic) by controlling the inflow rates of air and nitrogen. The $\mathrm{O}_{2}$ concentration was monitored continuously and after 3 days, mice were anesthetized and salivary glands were obtained and used for the study.
\end{abstract}

Cell viability assays. Cells were seeded on 96-well plates at a density of $0.5 \times 10^{5}$ cells/well. The cultures were grown for $24 \mathrm{~h}$ followed by the addition of fresh medium before the experiment. Cell viability was measured by using the MTT method. Twenty microliters of MTT reagent $(5 \mathrm{mg} / \mathrm{ml}$ MTT in PBS) was added to each well and incubated in a $\mathrm{CO}_{2}$ incubator for $4 \mathrm{~h}$. The resulting formazan dye was extracted with $100 \mu \mathrm{l}$ of $0.01 \mathrm{~N} \mathrm{HCl}$ in isopropanol and the absorbance was measured in a micro plate reader (Molecular Device, Sunnyvale, CA, USA) at 570 and $650 \mathrm{~nm}$. Cell viability was expressed as a percentage of the control culture.

Cell surface biotinylation, membrane preparations, and western blot analyses. Cells were collected and stored at $-80^{\circ} \mathrm{C}$. Crude lysates were prepared from SH-SY5Y, HSG cells, and salivary tissues, as described previously in Singh et al..$^{51}$ and Sukumarn et al..$^{52}$ Protein concentrations were determined using the Bradford reagent (Bio-Rad, Hercules, CA, USA), and $25-50 \mu \mathrm{g}$ of proteins were resolved on
4-12\% SDS-Tris-acetate gels, transferred to PVDF membranes and probed with respective antibodies Peroxidase conjugated respective secondary antibodies were used to label the proteins. The proteins were detected by enhanced chemiluminescence detection kit (SuperSignal West Pico; Pierce, Thermo Scientific, Waltham, MA, USA). Densitometric analysis was performed using imageJ analysis and results were corrected for protein loading by normalization for $\beta$-actin expression as described in Singh et al. ${ }^{51,53-55}$ For cell surface biotinylation, cells were treated as required and incubated for $20 \mathrm{~min}$ with $1.5 \mathrm{mg} / \mathrm{ml}$ Sulfo-NHS-LC-Biotin (Pierce) in PBS (pH 8.0) on ice and followed the protocol as mentioned before. ${ }^{5,56}$ Following biotin labeling, cells were washed and solubilized. Biotinylated proteins were pulled down with NeutrAvidin-linked beads (Pierce), resolved on $4-12 \%$ SDS-Tris-acetate gels, and individual proteins were detected by western blotting.

Confocal microscopy. For the immunofluorescence assays, the SH-SY5Y and HSG cells were grown overnight on coverslips. Cells were transfected with fluorescent-tagged LC3A plasmid using Lipofectamine 2000 in Opti-MEM medium as per supplier's instructions (Invitrogen) and treated with the desired chemicals. After $24 \mathrm{~h}$, the cells were washed twice with phosphate-buffered saline, and fixed for $30 \mathrm{~min}$ using $3 \%$ paraformaldehyde. Confocal images were collected using a MRC1024-krypton/argon laser scanning confocal equipped with a Zeiss LSM 510 Meta photomicroscope (Carl Zeiss, Jena, Germany).

Calcium measurement. Cells were incubated with $2 \mu \mathrm{M}$ fura-2 (Molecular Probes, Eugene, OR, USA) for $45 \mathrm{~min}$, washed twice with $\mathrm{Ca}^{2+}$-free SES (Standard External Solution, include: $10 \mathrm{mM}$ HEPES, $120 \mathrm{mM} \mathrm{NaCl}, 5.4 \mathrm{mM} \mathrm{KCl}, 1 \mathrm{mM}$ $\mathrm{MgCl} 2,10 \mathrm{mM}$ glucose, $\mathrm{pH}$ 7.4) buffer. For fluorescence measurements, the fluorescence intensity of Fura-2-loaded control cells was monitored with a CCD camera-based imaging system (Compix, Cranbery, PA, USA) mounted on an Olympus (Shinjuku, Tokyo, Japan) XL70 inverted microscope equipped with an Olympus $\times 40(1.3 \mathrm{NA})$ objective. A monochrometer dual wavelength enabled alternative excitation at 340 and $380 \mathrm{~nm}$, whereas the emission fluorescence was monitored at $510 \mathrm{~nm}$ with an Okra Imaging camera (Hamamatsu, Shizuoka Prefecture, Japan). The images of multiple cells collected at each excitation wavelength were processed using the $\mathrm{C}$ imaging, $\mathrm{PCl}$ software (Compix), to provide ratios of Fura-2 fluorescence from excitation at $340 \mathrm{~nm}$ to that from excitation at 
$380 \mathrm{~nm}$ (F340/F380). Dispersed salivary gland cells were placed on glass-bottom poly-D lysine plates and used for the study. Fluorescence traces shown represent $\left[\mathrm{Ca}^{2+}\right]_{i}$ values that are averages from at least $30-40$ cells and are a representative of results obtained in at least three to four individual experiments. $\left[\mathrm{Ca}^{2+}\right]_{i}$ in individual cells was estimated on the basis of the Grynkiewicz equation formula: $\left[\mathrm{Ca}^{2+}\right]_{\mathrm{i}}=K_{\mathrm{D}} \times B \times\left(R-R_{\min }\right) /\left(R_{\max }-R\right)$, where $K_{\mathrm{D}}$ is the indicator's dissociation constant for $\mathrm{Ca}^{2+}(0.22 \mu \mathrm{M}) ; R$ is ratio of fluorescence intensity at two different wavelengths $(340 / 380 \mathrm{~nm}) ; R_{\max }$ and $R_{\min }$ are the ratios of $\mathrm{Ca}^{2+}$-free and $\mathrm{Ca}^{2}$ ${ }^{+}$-bound Fura-2, respectively; and $B$ is the ratio of the fluorescence intensity of the second excitation wavelength at zero and saturating $\mathrm{Ca}^{2+}$ concentrations. ${ }^{57}$ The bar diagram shown in the figures represents the $\left[\mathrm{Ca}^{2+}\right]_{\mathrm{i}}$ in nanomolar concentrations.

Electrophysiology. For patch clamp experiments, coverslips with cells were transferred to the recording chamber and perfused with an external Ringer's solution of the following composition (mM): $\mathrm{NaCl}, 145 ; \mathrm{CsCl}, 5 ; \mathrm{MgCl}_{2}, 1 ; \mathrm{CaCl}_{2}, 1$; Hepes, 10; Glucose, 10; pH 7.3 (NaOH). For Na-based divalent ion-free (DVF), the external solutions contained (mM) $165 \mathrm{NaCl}, 5 \mathrm{CsCl}, 10$ EDTA, 10 HEPES and 10 glucose, $\mathrm{pH}$ 7.4. Whole-cell currents were recorded using an Axopatch 200B (Axon Instruments, Sunnyvale, CA, USA). The patch pipette had resistances between 3 and $5 \mathrm{M}$ after filling with the standard intracellular solution that contained the following (mM): cesium methane sulfonate, 150; $\mathrm{NaCl}$, 8; Hepes, 10; EGTA, 10; pH $7.2(\mathrm{CsOH})$. With a holding potential $0 \mathrm{mV}$, voltage ramps ranging from $-100 \mathrm{mV}$ to $+100 \mathrm{mV}$ and $100 \mathrm{~ms}$ duration were delivered at 2-s intervals after whole-cell configuration was formed. Currents were recorded at $2 \mathrm{kHz}$ and digitized at 5-8 kHz. pClamp 10.1 software was used for data acquisition and analysis. Basal leaks were subtracted from the final currents and average currents are shown. All experiments were carried out under room temperature.

Statistics. Data analysis was performed using MicroSoft Excel or Origin 7.0 (OriginLab) and Graphpad prism 6.0. Statistical comparisons were made using one-way ANOVA. Experimental values are expressed as means \pm S.E.M. Differences in the mean values were considered to be significant at ${ }^{*} P<0.05$ or ${ }^{* *} P<0.01$, respectively.

\section{Conflict of Interest}

The authors declare no conflict of interest.

Acknowledgements. We thank the confocal facility at UND, which is partially supported by NIH (P30GM103329). We also duly acknowledge grant support from the NIH (DE017102) awarded to B.B.S.

1. Kato M, Ospelt C, Gay RE, Gay S, Klein K. Dual role of autophagy in stress-induced cell death in rheumatoid arthritis synovial fibroblasts. Arthritis Rheumatol 2014; 66: $40-48$.

2. Murrow L, Debnath J. Autophagy as a stress-response and quality-control mechanism: implications for cell injury and human disease. Annu Rev Pathol 2013; 8: 105-137.

3. Zhang Y, Calderwood SK. Autophagy, protein aggregation and hyperthermia: a mini-review. Int J Hyperthermia 2011; 27: 409-414.

4. Smaili SS, Pereira GJS, Costa MM, Rocha KK, Rodrigues L, do Carmo LG et al. The role of calcium stores in apoptosis and autophagy. Curr Mol Med 2013; 13: 252-265.

5. Ouyang L, Shi Z, Zhao S, Wang FT, Zhou TT, Liu B et al. Programmed cell death pathways in cancer: a review of apoptosis, autophagy and programmed necrosis. Cell Prolif 2012; 45 : 487-498.

6. Ravikumar B, Sarkar S, Davies JE, Futter M, Garcia-Arencibia M, Green-Thompson ZW et al. Regulation of mammalian autophagy in physiology and pathophysiology. Physiol Rev 2010; 90: $1383-1435$.

7. Su J, Zhou L, Kong X, Yang X, Xiang X, Zhang $Y$ et al. Endoplasmic reticulum is at the crossroads of autophagy, inflammation, and apoptosis signaling pathways and participates in the pathogenesis of diabetes mellitus. J Diabetes Res 2013; 2013: 193461.

8. Badger JL, Cordero-Llana O, Hartfield EM, Wade-Martins R. Parkinson's disease in a dishUsing stem cells as a molecular tool. Neuropharmacology 2014; 76 Pt A: 88-96.

9. McBrayer M, Nixon RA. Lysosome and calcium dysregulation in Alzheimer's disease: partners in crime. Biochem Soc Trans 2013; 41: 1495-1502.

10. Berridge MJ, Bootman MD, Roderick HL. Calcium signalling: dynamics, homeostasis and remodelling. Nat Rev Mol Cell Biol 2003; 4: 517-529.

11. Smyth JT, Putney JW. Regulation of store-operated calcium entry during cell division Biochem Soc Trans 2012; 40: 119-123.

12. Abramowitz J, Birnbaumer L. Physiology and pathophysiology of canonical transient receptor potential channels. FASEB J 2009; 23: 297-328.
13. Lof C, Viitanen T, Sukumaran P, Tornquist K. TRPC2: of mice but not men. Adv Exp Med Biol 2011; 704: 125-134.

14. Borle $\mathrm{AB}$. Control, modulation, and regulation of cell calcium. Rev Physiol Biochem Pharmacol 1981; 90: 13-153.

15. Decuypere JP, Bultynck G, Parys JB. A dual role for $\mathrm{Ca}(2+)$ in autophagy regulation. Cell Calcium 2011; 50: 242-250.

16. Criollo A, Maiuri MC, Tasdemir E, Vitale I, Fiebig AA, Andrews D et al. Regulation of autophagy by the inositol trisphosphate receptor. Cell Death Differ 2007; 14: 1029-1039.

17. Vicencio JM, Ortiz C, Criollo A, Jones AW, Kepp O, Galluzzi L et al. The inosito 1,4,5-trisphosphate receptor regulates autophagy through its interaction with Beclin 1. Cell Death Differ 2009; 16: 1006-1017.

18. Khan MT, Joseph SK. Role of inositol trisphosphate receptors in autophagy in DT40 cells. J Biol Chem 2010; 285: 16912-16920.

19. Buytaert E, Callewaert G, Hendrickx N, Scorrano L, Hartmann D, Missiaen L et al. Role of endoplasmic reticulum depletion and multidomain proapoptotic BAX and BAK proteins in shaping cell death after hypericin-mediated photodynamic therapy. FASEB J 2006; 20: 756-758.

20. Wang SH, Shih YL, Ko WC, Wei YH, Shih CM. Cadmium-induced autophagy and apoptosis are mediated by a calcium signaling pathway. Cell Mol Life Sci 2008; 65: 3640-3652.

21. Hoyer-Hansen M, Bastholm L, Szyniarowski P, Campanella M, Szabadkai G, Farkas T et al. Control of macroautophagy by calcium, calmodulin-dependent kinase kinase-beta, and Bcl-2. Mol Cell 2007; 25: 193-205.

22. Pani $B$, Bollimuntha $S$, Singh $B B$. The TR (i)P to $\mathrm{Ca}(2)(+)$ signaling just got STIMy: an update on STIM1 activated TRPC channels. Front Biosci (Landmark Ed) 2012; 17: 805-823.

23. Bjorkoy G, Lamark T, Pankiv S, Overvatn A, Brech A, Johansen T. Monitoring autophagic degradation of p62/SQSTM1. Methods Enzymol 2009; 452: 181-197.

24. Bai $\mathrm{H}$, Inoue J, Kawano T, Inazawa J. A transcriptional variant of the LC3A gene is involved in autophagy and frequently inactivated in human cancers. Oncogene 2012; 31: 4397-4408.

25. Liu X, Wang W, Singh BB, Lockwich T, Jadlowiec J, O'Connell B et al. Trp1, a candidate protein for the store-operated $\mathrm{Ca}(2+)$ influx mechanism in salivary gland cells. J Biol Chem 2000; 275: 3403-3411.

26. Apati A, Janossy J, Brozik A, Bauer PI, Magocsi M. Calcium induces cell survival and proliferation through the activation of the MAPK pathway in a human hormone-dependent leukemia cell line, TF-1. J Biol Chem 2003; 278: 9235-9243.

27. Liu X, Cheng KT, Bandyopadhyay BC, Pani B, Dietrich A, Paria BC et al. Attenuation of storeoperated $\mathrm{Ca} 2+$ current impairs salivary gland fluid secretion in TRPC1(-/-) mice. Proc Natl Acad Sci USA 2007; 104: 17542-17547.

28. Pani B, Liu X, Bollimuntha S, Cheng KT, Niesman IR, Zheng C et al. Impairment of TRPC1. STIM1 channel assembly and AQP5 translocation compromise agonist-stimulated fluid secretion in mice lacking caveolin1. J Cell Sci 2013; 126: 667-675.

29. Singh BB, Zheng C, Liu X, Lockwich T, Liao D, Zhu MX et al. Trp1-dependent enhancement of salivary gland fluid secretion: role of store-operated calcium entry. FASEB J 2001; 15: 1652-1654.

30. Cheng KT, Ong HL, Liu X, Ambudkar IS. Contribution of TRPC1 and Orai1 to $\mathrm{Ca}(2+)$ entry activated by store depletion. Adv Exp Med Biol 2011; 704: 435-449.

31. Gordon PB, Holen I, Fosse M, Rotnes JS, Seglen PO. Dependence of hepatocytic autophagy on intracellularly sequestered calcium. J Biol Chem 1993; 268: 26107-26112.

32. Sukumaran P, Löf C, Pulli I, Kemppainen K, Viitanen T, Törnquist K. Significance of the transient receptor potential canonical 2 (TRPC2) channel in the regulation of rat thyroid FRTL-5 cell proliferation, migration, adhesion and invasion. Mol Cell Endocrinol 2013; 374: $10-21$.

33. Kondratskyi A, Yassine M, Kondratska K, Skryma R, Slomianny C, Prevarskaya N. Calcium-permeable ion channels in control of autophagy and cancer. Front Physiol 2013; $4: 272$.

34. Prevarskaya N, Skryma R, Shuba Y. Calcium in tumour metastasis: new roles for known actors. Nat Rev Cancer 2011; 11: 609-618.

35. De A, Krueger JM, Simasko SM. Tumor necrosis factor alpha increases cytosolic calcium responses to AMPA and KCl in primary cultures of rat hippocampal neurons. Brain Res 2003; 981: 133-142.

36. Imanishi T, Matsushima K, Kawaguchi A, Wada T, Yoshida S, Ichida S. Increased response to high $\mathrm{KCl}$-induced elevation in the intracellular- $\mathrm{Ca}(2+)$ concentration in differentiated NG108-15 cell and the inhibitory effect of the L-type $\mathrm{Ca}(2+)$ channel blocker, calciseptine. Neurochem Res 2006; 31: 33-40.

37. Pivovarova NB, Andrews SB. Calcium-dependent mitochondrial function and dysfunction in neurons. FEBS J 2010; 277: 3622-3636.

38. Cole K, Kohn E. Calcium-mediated signal transduction: biology, biochemistry, and therapy. Cancer Metastasis Rev 1994; 13: 31-44.

39. Harr MW, Distelhorst CW. Apoptosis and autophagy: decoding calcium signals that mediate life or death. Cold Spring Harb Perspect Biol 2010; 2: a005579.

40. Sarkar S, Floto RA, Berger Z, Imarisio S, Cordenier A, Pasco M et al. Lithium induces autophagy by inhibiting inositol monophosphatase. J Cell Biol 2005; 170: 1101-1111.

41. Higo T, Hamada K, Hisatsune C, Nukina N, Hashikawa T, Hattori M et al. Mechanism of ER stress-induced brain damage by IP(3) receptor. Neuron 2010; 68: 865-878.

42. Law BY, Wang M, Ma DL, Al-Mousa F, Michelangeli F, Cheng SH et al. Alisol B, a novel inhibitor of the sarcoplasmic/endoplasmic reticulum $\mathrm{Ca}(2+)$ ATPase pump, induces autophagy, endoplasmic reticulum stress, and apoptosis. Mol Cancer Ther 2010; 9: 718-730. 
43. Jia W, Pua HH, Li QJ, He YW. Autophagy regulates endoplasmic reticulum homeostasis and calcium mobilization in T lymphocytes. J Immunol 2011; 186: 1564-1574.

44. Grotemeier A, Alers S, Pfisterer SG, Paasch F, Daubrawa M, Dieterle A et al. AMPK-independent induction of autophagy by cytosolic Ca2+ increase. Cell Signal 2010; 22: 914-925.

45. Sakaki K, Wu J, Kaufman RJ. Protein kinase Ctheta is required for autophagy in response to stress in the endoplasmic reticulum. J Biol Chem 2008; 283: 15370-15380.

46. Brady NR, Hamacher-Brady A, Yuan H, Gottlieb RA. The autophagic response to nutrient deprivation in the $\mathrm{hl}-1$ cardiac myocyte is modulated by $\mathrm{Bcl}-2$ and sarco/endoplasmic reticulum calcium stores. FEBS J 2007; 274: 3184-3197.

47. Gastaldello A, Callaghan H, Gami P, Campanella M. Ca 2+ -dependent autophagy is enhanced by the pharmacological agent PK11195. Autophagy 2010; 6: 607-613.

48. Knoferle J, Koch JC, Ostendorf T, Michel U, Planchamp V, Vutova P et al. Mechanisms of acute axonal degeneration in the optic nerve in vivo. Proc Natl Acad Sci USA 2010; 107: 6064-6069.

49. Sun Y, Sukumaran P, Varma A, Derry S, Sahmoun AE, Singh BB. Cholesterol-induced activation of TRPM7 regulate cell proliferation, migration, and viability of human prostate cells. Biochim Biophys Acta 2014; 1843: 1839-1850.

50. Sun Y, Selvaraj S, Varma A, Derry S, Sahmoun AE, Singh BB. Increase in serum Ca2+/Mg2+ ratio promotes proliferation of prostate cancer cells by activating TRPM7 channels. J Biol Chem 2013; 288: 255-263.

51. Singh BB, Lockwich TP, Bandyopadhyay BC, Liu X, Bollimuntha S, Brazer SC et al. VAMP2-dependent exocytosis regulates plasma membrane insertion of TRPC3 channels and contributes to agonist-stimulated Ca2+ influx. Mol Cell 2004; 15: 635-646.

52. Sukumaran $P$, Löf $C$, Kemppainen $K$, Kankaanpää $P$, Pulli I, Näsman J et al. Canonical transient receptor potential channel 2 (TRPC2) as a major regulator of calcium homeostasis in rat thyroid FRTL-5 cells: importance of PKC $\delta$ and STIM2. J Biol Chem 2012; 287: 44345-44360.
53. Selvaraj S, Watt JA, Singh BB. TRPC1 inhibits apoptotic cell degeneration induced by dopaminergic neurotoxin MPTP/MPP(+). Cell Calcium 2009; 46: 209-218.

54. Löf C, Sukumaran $\mathrm{P}$, Viitanen $\mathrm{T}$, Vainio $\mathrm{M}$, Kemppainen $\mathrm{K}$, Pulli I et al. Communication Between the Calcium and cAMP Pathways Regulate the Expression of the TSH Receptor: TRPC2 in the Center of Action. Mol Endocrinol 2012; 26 : 2046-2057.

55. Pani B, Ong HL, Brazer SC, Liu X, Rauser K, Singh BB et al. Activation of TRPC1 by STIM1 in ER-PM microdomains involves release of the channel from its scaffold caveolin-1. Proc Natl Acad Sci USA 2009; 106: 20087-20092.

56. Liou J, Fivaz M, Inoue T, Meyer T. Live-cell imaging reveals sequential oligomerization and local plasma membrane targeting of stromal interaction molecule 1 after $\mathrm{Ca} 2+$ store depletion. Proc Natl Acad Sci USA 2007; 104: 9301-9306.

57. Zhang S, Hyrc K, Wang S, Wice BM. Xenin-25 increases cytosolic free calcium levels and acetylcholine release from a subset of myenteric neurons. Am J Physiol Gastrointest Liver Physiol 2012; 303: G1347-G1355.

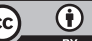

Cell Death and Disease is an open-access journal published by Nature Publishing Group. This work is licensed under a Creative Commons Attribution 4.0 International License. The images or other third party material in this article are included in the article's Creative Commons license, unless indicated otherwise in the credit line; if the material is not included under the Creative Commons license, users will need to obtain permission from the license holder to reproduce the material. To view a copy of this license, visit http://creativecommons.org/licenses/by/4.0/ 